\title{
Implementation of Lean Manufacturing and Waste Minimization to Overcome Delay in Metering Regulating System Fabrication Process using Value Stream Mapping and VALSAT Method Approach (Case Study: Company YS)
}

\author{
Muhammad Kholila, Farichatus Sa'diyah' ${ }^{b}$, Adizty Suparno a, Sulaiman Bin H Hasan ${ }^{c}$ \\ ${ }^{a}$ Department of Industrial Engineering, Faculty of Engineering, Universitas Mercu Buana, Jakarta, Indonesia \\ bIndustrial Engineering Bachelor Programme, Faculty of Engineering, Universitas Mercu Buana, Indonesia \\ ${ }^{c}$ Department of Industrial and Engineering Management, Faculty of Mechanical and Manufacturing \\ Engineering, Universiti Tun Hussein Onn Malaysia (UTHM), Johor, Malaysia
}

\begin{abstract}
Company YS participates in managing the natural gas network by creating a Metering Regulating System (MRS), which is a tool to measure gas usage and damage to the natural gas network. Based on the data obtained, the MRS delivery process was often not in accordance with the agreed schedule, there was a delay of up to $46 \%$, namely 50 days late from the planned schedule. To overcome these delays, waste reduction is carried out by mapping the overall condition of the company in Value Stream Mapping (VSM) and mapping in detail with the Value Stream Mapping Analysis Tools (VALSAT). In the VSM method, a Current Value Stream Mapping is carried out which then identifies the waste in which the correlation score between the wastes is described in a matrix called the Waste Relationship Matrix then followed by the calculation of the Waste Assessment Questionnaire. Then in the VALSAT method, further waste identification was carried out using seven tools. The most influential percentage of waste that has been obtained is then searched for the root cause using a fishbone diagram and then eliminated and depicted in the Future Value Stream Mapping. The most influential waste in the fabrication process is Waiting and after repairs according to the recommendations, the lead time is obtained from $41,822.60$ minutes or 99 working days to $35,055.60$ minutes or 83 working days so that the fabrication process can be completed 3 days faster than scheduled.
\end{abstract}

Keywords: lean manufacturing; value stream mapping; value stream mapping analysis tools

DOI: $10.37869 /$ ijatec.v2i1.41

Received 19 February 2021; Accepted 16 March 2021; Available online 19 April 2021

(c) The Authors. Published by IRIS. This is an open access article under the CC BY-NC-SA license @) (1) @()

\section{Introduction}

Given the increasing scarcity of fuel oil, the Indonesian government is increasingly exploiting the use of Natural Gas or often called LNG. LNG or Natural Gas is increasingly in demand because it is cheaper than fossil fuels such as kerosene. The government and the private sector fulfill the people's need for gas by producing LNG and distributing natural gas directly to the community. In terms of natural gas distribution work, Company YS is involved in managing the natural gas network by creating a Metering Regulating System, which is a tool to measure gas usage and damage to the natural gas network. Metering Regulating System is a series of various components which are assembled into a single unit system which is one of the complete supporting units in gas distribution.

The MRS procurement process is based on the time duration specified in the work contract according to customer requests. However, in practice, the MRS delivery process is often not in accord 
ance with agreed schedule, so this has an impact on the point of penalty that will be received by the company. This delay is of course due to waste in production activities so that it is not yet effective and efficient, especially in the fabrication process. The demand to find new ways to provide added value to customers is getting stronger so that in the tender for the next natural gas network project, Company YS has always been the trusted company in providing the Metering Regulating System. Therefore, it is necessary to improve and evaluate the fabrication process by eliminating waste. The following is the data for the procurement work for the Metering Regulating System Company YS from 2016 to 2018.

Table 1. Job Data for metering regulating system procurement at company YS

\begin{tabular}{|c|c|c|c|c|c|c|}
\hline Year & Project Name & Customer & Planning & Actual & Overdue & $\%$ \\
\hline 2018 & $\begin{array}{l}\text { Procurement of } 2018 \text { Household } \\
\text { Natural Gas Network MRS / Hospital }\end{array}$ & $\begin{array}{c}\text { Company } \\
\text { Pertamina Gas }\end{array}$ & 86 day & 99 day & 13 day & 15 \\
\hline 2018 & $\begin{array}{l}\text { MRS / RS Procurement Work for the } \\
\text { Jargas Medan - Deli Serdang Project } \\
2018\end{array}$ & Company PGN & 75 day & 75 day & - & 0 \\
\hline 2018 & $\begin{array}{l}\text { MRS / RS Procurement Work for the } \\
\text { Jargas Project Medan - Deli Serdang } \\
\text { Tarakan } 2018\end{array}$ & Company PGN & 35 day & 35 day & - & 0 \\
\hline 2018 & $\begin{array}{l}\text { Procurement and Installation of PT. } \\
\text { Pertamina Gas for PT. Sustainable } \\
\text { Vegetable Industry }\end{array}$ & $\begin{array}{l}\text { Company } \\
\text { Pertamina Gas }\end{array}$ & 28 day & 39 day & 11 day & 39 \\
\hline 2017 & $\begin{array}{l}\text { Procurement and Installation of } \\
\text { Metering Packages for the Pelita } \\
\text { Cengkareng Paper Gas Pipe } \\
\text { Construction Project }\end{array}$ & $\begin{array}{l}\text { Company } \\
\text { Pertamina Gas }\end{array}$ & 40 day & 41 day & 1 day & 3 \\
\hline 2017 & $\begin{array}{l}\text { Procurement and Installation of } \\
\text { Metering Packages for the Pasuruan } \\
\text { PIER Gas Pipe Construction Project } \\
\text { Procurement of Natural Gas Network }\end{array}$ & $\begin{array}{l}\text { Company } \\
\text { Pertamina Gas }\end{array}$ & 40 day & 42 day & 2 day & 5 \\
\hline 2016 & $\begin{array}{l}\text { Materials for Households in Batam } \\
\text { City - Riau Islands }\end{array}$ & Company PGN & 59 day & 71 day & 12 day & 20 \\
\hline 2016 & $\begin{array}{l}\text { Procurement of Natural Gas Network } \\
\text { Materials for Households in the City } \\
\text { of Balikpapan, East Kalimantan } \\
\text { Province }\end{array}$ & Company PGN & 53 day & 70 day & 17 day & 32 \\
\hline 2016 & $\begin{array}{l}\text { Development of Distribution } \\
\text { Network for West Java and Southern } \\
\text { Sumatra } 3\end{array}$ & Company PGN & 109 day & $\begin{array}{l}159 \\
\text { day }\end{array}$ & 50 day & 46 \\
\hline 2016 & $\begin{array}{l}\text { Procurement of Metering Regulating } \\
\text { Station (MR / S) in } 2016\end{array}$ & Company PGN & 100 day & $\begin{array}{l}100 \\
\text { day }\end{array}$ & - & 0 \\
\hline
\end{tabular}

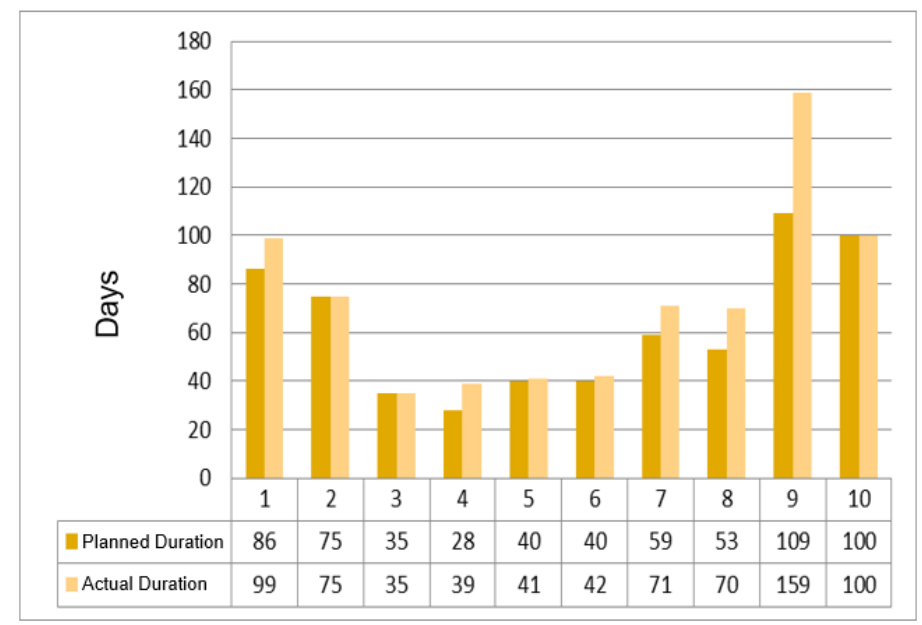

Figure 1. Comparison of planning duration \& actual duration of metering regulating system procurement project 
From the data tables and graphs above, it can be concluded that the MRS fabrication completion schedule is still quite late, some of which even reach $46 \%$, which is 50 days late from the planned schedule. From the research results [1] Analysis Of Production Process To Improve Lead Time And Productivity In Fabrication By Using Lean Methodology. Case Study In Turbine Component Manufacture Company found that the application of Lean Manufacturing with the Value Stream Analysis Tools (VALSAT) method identifies the waste that occurs using the Value Stream Analysis Tools method and provides suggestions for improvements to the clip production process so that after implementing all improvement ideas, time increases from 193 days to 176 days (reduce 9\%) and inventory also decreased from 27 days to 12 days (55\%). In addition, the results of research [2] found that the application of the VSM method with the 7 waste approach can reduced transportation time at several work stations so that at the end of the study it resulted in a $0.33 \%$ increase in production time of mackerel fish crackers in Small and Medium Enterprises (UKM).

Therefore, to overcome the problem of delays in the fabrication process, it is necessary to control production, namely actions that ensure that all activities carried out in planning are in accordance with predetermined targets [3]. In the process of controlling, Company YS can find the source of the problem or waste that occurs for the repair process. The identification of waste and improvement of the fabrication process is carried out by implementing Lean Manufacturing. Lean Manufacturing is an approach to streamline the system by eliminating waste. By grouping activities into value added and non-value added, it can be seen which activities can provide added value and which do not provide added value, so that appropriate steps can be taken for recommendations for improvement so that an effective and efficient fabrication process is achieved. To make improvements by reducing waste, the method used in this research is mapping the overall condition of the company in Value Stream Mapping and mapping in detail with the Value Stream Mapping Analysis Tools (VALSAT).

Lean Manufacturing is an effort for product efficiency or a continuous effort to eliminate waste (waste) and increase the added value (value-added) of products (goods/services) to provide value to customers (customer value) [4]. APICS Dictionary [5] defines Lean as a business philosophy based on minimizing resources (including time) in various company activities. [5] states that Lean focuses on the identification and elimination of non-value-adding activities in design, production (for manufacturing) or operations (for services), and supply chain management, which directly with customers. That statement supported [6] with employee manpower involve in the thinking process organization.

According to Taiichi Ohno in the journal [7], the Toyota Production System's inventor, lean manufacturing is all activities until the producer earns cash. The focus of lean manufacturing is reducing the timeline by eliminating non-value-added waste. TPS (Toyota Production System) puts its all effort to completely eliminate waste, avoid overburden and uneven work in all sectors to enable its members to work efficient and effectively [8]-[10]. TPS having high standard, ensures the method used is safe and the approach is consistent to get the best quality. Toyota Members always keep improving their standard and procedures to get the best result, increase efficiency, and eradicate wastefulness [11], [12]. Lean manufacturing or equal to the Toyota Production System at its core, is a production system. It aims to eliminate waste (waste) in all aspects of production, from the flow of raw materials from suppliers to the final product's flow to the consumer, via continuous improvement to increase output and productivity[13]. Waste can be reduced by producing at the right amount, at the right time, and in the right place (just in time concept) [14]. Continuous improvement is a gradual improvement action that is carried out continuously. Lean is a continuous effort to eliminate waste, increase value added products of goods and services including provide value to customers called customer value [15]. Lean has more general characteristics compared to TPS which has Japanese cultural principle [16]. [17] has conducted research by applying lean principles and providing development to the output of a manufacturing industry.

Value Stream Mapping is a lean manufacturing tool that helps us understand the flow of materials and information in a process [18]. Value stream mapping includes all activities that add value and do not add value needed to process a product from raw materials to delivery to customers. In other words, value stream mapping is a chart of the manufacturing cycle of a product that shows each stage in the production process [5]. According to Hartini in [2], the purpose of value stream mapping is to identify the waste of resources and help make the area off-target for an actual 
improvement process. VSM is used to find out the waste in several workstation units and make targets for time efficiency improvement to achieve a better production process in this research.

The Value Stream Analysis Tool (VALSAT) is a tool that can be used to minimize waste in the production process. In this VALSAT, seven tools will be used to analyze these wastes. The value stream mapping with the largest total score according to the VALSAT results will be used as the selected mapping to identify waste in detail. This selection is based on how the value stream mapping with the largest value is most suitable for identifying waste in the value stream. VALSAT is an approach used by weighting the waste, and then from the weighting, the tool is selected using a matrix.

There are seven tools can be used: Process Activity Mapping, Supply Chain Response Matrix, Production Variety Funnel, Quality Filter Mapping, Demand Amplification Mapping, Decision Point Analysis, and Physical Structure.

After getting the weight of each waste, the next step is selecting a detailed mapping tool that matches the type of waste in the production process. The detailed mapping tool is chosen based on the weight calculation on the value stream analysis (VALSAT). The weight calculation on VALSAT has done by multiplying the weight of waste obtained from the questionnaire with the multiplying factor of the relationship between waste and the detailed mapping tool. [19] and [20] occurred VALSAT analysis to in order to overcome waste and got improvement prioritize to reduce the waste.

Production activities are part of the company's organizational functions, responsible for processing raw materials into finished goods/end products that the company can sell. A series of activities are needed that will form a production system to carry out this production function [3]. One of the production functions is the production process itself. According to [21], a process is a series of ways, steps, or techniques for changing the available raw materials (labor, machines, raw materials, and supporting facilities), which transform to obtain the desired result or product. Production is transforming raw materials into semi-finished goods or semi-finished goods into finished goods valued through a series of processes that require energy at each stage [22]. There is a change in geometric, structural, or chemical characteristics. Types of Production Processes In supporting production activities in the industrial world, they usually use various good production processes. If the production process from a manufacturing system point of view, it consists of the kinds of methods Make To Stock (MTS), Assemble To Order (ATO), Make To Order (MTO), and Engineering To Order (ETO) [23].

Previous research in [2], [19], and [20] did VALSAT and VSM separately. There are still few studies that merge VSM and VALSAT especially for oil and gas company. [24] conduct a research for oil and gas company with VSM but focusing in maintenance scope. In other hand [25] also did research to implement Lean for oil and gas sector framework with focusing in identification by using six sigma tools. [26] and [27] also combine VSM and VALSAT in rubber and pile production process and success to reduce waste. [28] implement VSM and VALSAT for the production process of palm oil giving new insight about waiting waste. Those research encourage this study to implement it as Company YS solution for metering regulating system in fabrication process which an oil and gas company.

\section{Research Methodology}

The study, entitled "Implementation of Lean Manufacturing and Waste Minimization to Overcome Delays in the Metering Regulating System Fabrication Process with the VSM and VALSAT Method Approach (Case Study: Company YS)" aims to determine the causes of errors, looking at activities that cannot add value or waste that occurs and provides recommendations for improvements in minimizing waste with the VSM and VALSAT methods so that the Measurement Control System fabrication process does not experience improvement. This type of case study approach is a type of approach used to understand and understand the events or problems that have occurred by collecting various kinds of information from sources which are then processed to obtain a solution so that the problem revealed can be resolved. There is a depth analysis in this case study so that this type of research falls into a qualitative type.

The data was collected for the 2018 MRS procurement project data, namely "Procurement of 2018 Household Natural Gas Network MRS / Hospital" who experienced a delay of 11 days. Data cycle time is the time required to make 1 unit of product per one workstation, cycle time is needed as input in 
the entire product process. This data was obtained from the 2018 Household Natural Gas Network MRS / RS Procurement project data. The data was obtained through project control from the fabrication party and by the MRS specialist Supervisor Company YS.

Table 2. Cycle time of MRS fabrication process (minutes)

\begin{tabular}{|c|c|c|c|c|c|c|c|c|c|c|c|c|}
\hline No & $\begin{array}{c}\text { Mark } \\
\text { ing }\end{array}$ & $\begin{array}{c}\text { Cutti } \\
\text { ng }\end{array}$ & $\begin{array}{l}\text { Fit } \\
\text { Up }\end{array}$ & $\begin{array}{c}\text { Weldi } \\
\text { ng }\end{array}$ & $\begin{array}{l}\text { Radio } \\
\text { graphy }\end{array}$ & $\begin{array}{c}\text { Dimensi } \\
\text { onal } \\
\text { Check }\end{array}$ & $\begin{array}{l}\text { Hydr } \\
\text { otest }\end{array}$ & $\begin{array}{l}\text { Sand } \\
\text { blast }\end{array}$ & $\begin{array}{c}\text { Paint } \\
\text { ing }\end{array}$ & $\begin{array}{l}\text { Paint } \\
\text { Repor } \\
\quad \text { t }\end{array}$ & $\begin{array}{c}\text { Assem } \\
\text { bly }\end{array}$ & FAT \\
\hline 1 & 60 & 300 & 180 & 517,5 & 270 & 20 & 480 & 45 & 720 & 9 & 960 & 720 \\
\hline 2 & 65 & 328 & 194 & 552 & 273 & 25 & 480 & 42 & 750 & 5 & 720 & 750 \\
\hline 3 & 75 & 327 & 187 & 527 & 265 & 23 & 480 & 38 & 720 & 6 & 840 & 720 \\
\hline 4 & 62 & 302 & 185 & 535 & 260 & 23 & 480 & 37 & 730 & 7 & 960 & 730 \\
\hline 5 & 77 & 322 & 197 & 533 & 255 & 22 & 480 & 36 & 740 & 7,5 & 720 & 740 \\
\hline 6 & 62 & 328 & 193 & 552 & 275 & 20 & 480 & 38 & 750 & 6 & 960 & 750 \\
\hline 7 & 73 & 317 & 194 & 540 & 275 & 22,5 & 480 & 36 & 750 & 8 & 720 & 750 \\
\hline 8 & 65 & 328 & 194 & 552 & 273 & 23 & 480 & 44 & 750 & 10 & 720 & 750 \\
\hline 9 & 78 & 320 & 194 & 529 & 248 & 24 & 480 & 38 & 740 & 8,5 & 840 & 740 \\
\hline 10 & 65 & 328 & 194 & 552 & 273 & 25 & 480 & 40 & 750 & 6 & 960 & 750 \\
\hline 11 & 74 & 327 & 181 & 550 & 261 & 20 & 480 & 45 & 720 & 5 & 720 & 720 \\
\hline 12 & 78 & 313 & 194 & 546 & 269 & 19 & 480 & 37 & 750 & 5,5 & 960 & 750 \\
\hline 13 & 72 & 315 & 179 & 520 & 248 & 20 & 480 & 35 & 715 & 10 & 744 & 715 \\
\hline 14 & 64 & 307 & 200 & 547 & 277 & 20,5 & 480 & 37 & 750 & 9,7 & 816 & 750 \\
\hline 15 & 75 & 310 & 195 & 540 & 255 & 22 & 480 & 40 & 740 & 5 & 912 & 740 \\
\hline 16 & 68 & 326 & 197 & 552 & 277 & 23 & 480 & 41 & 730 & 7 & 864 & 730 \\
\hline 17 & 81 & 330 & 197 & 527 & 280 & 273 & 480 & 35 & 720 & 7,5 & 912 & 720 \\
\hline 18 & 75 & 328 & 194 & 517,5 & 255 & 248 & 480 & 38 & 750 & 6 & 960 & 750 \\
\hline 19 & 62 & 317 & 181 & 546 & 275 & 273 & 480 & 40 & 720 & 10 & 936 & 720 \\
\hline 20 & 77 & 328 & 194 & 540 & 275 & 261 & 480 & 45 & 730 & 8 & 720 & 730 \\
\hline 21 & 62 & 307 & 179 & 552 & 273 & 269 & 480 & 37 & 740 & 8,5 & 768 & 740 \\
\hline 22 & 73 & 310 & 195 & 529 & 248 & 248 & 480 & 37 & 750 & 6 & 720 & 750 \\
\hline 24 & 78 & 330 & 185 & 517 & 261 & 277 & 480 & 38 & 750 & 5 & 864 & 750 \\
\hline 25 & 65 & 328 & 197 & 547 & 269 & 248 & 480 & 36 & 740 & 5 & 888 & 750 \\
\hline 26 & 74 & 310 & 193 & 540 & 248 & 273 & 480 & 40 & 750 & 7 & 744 & 740 \\
\hline 27 & 78 & 326 & 194 & 546 & 277 & 255 & 480 & 40 & 720 & 6 & 792 & 750 \\
\hline 28 & 62 & 330 & 179 & 537 & 248 & 273 & 480 & 37 & 750 & 7 & 753,6 & 720 \\
\hline 29 & 73 & 317 & 195 & 540 & 273 & 265 & 480 & 42 & 730 & 10 & 720 & 750 \\
\hline 30 & 65 & 328 & 193 & 527 & 255 & 273 & 480 & 43 & 720 & 7,5 & 912 & 730 \\
\hline 31 & 62 & 310 & 181 & 560 & 273 & 248 & 480 & 40 & 720 & 6 & 960 & 720 \\
\hline 32 & 65 & 317 & 185 & 555 & 265 & 273 & 480 & 39 & 740 & 10 & 936 & 720 \\
\hline
\end{tabular}

Based on the flow of information, material flow and cycle time of the production process, the data is poured into the VSM form to describe the current conditions occurring in the company. After the flow of information and materials is formed, additional information is entered regarding the number of workers and the duration of the work. The current condition map image can be seen in Figure 2 . 


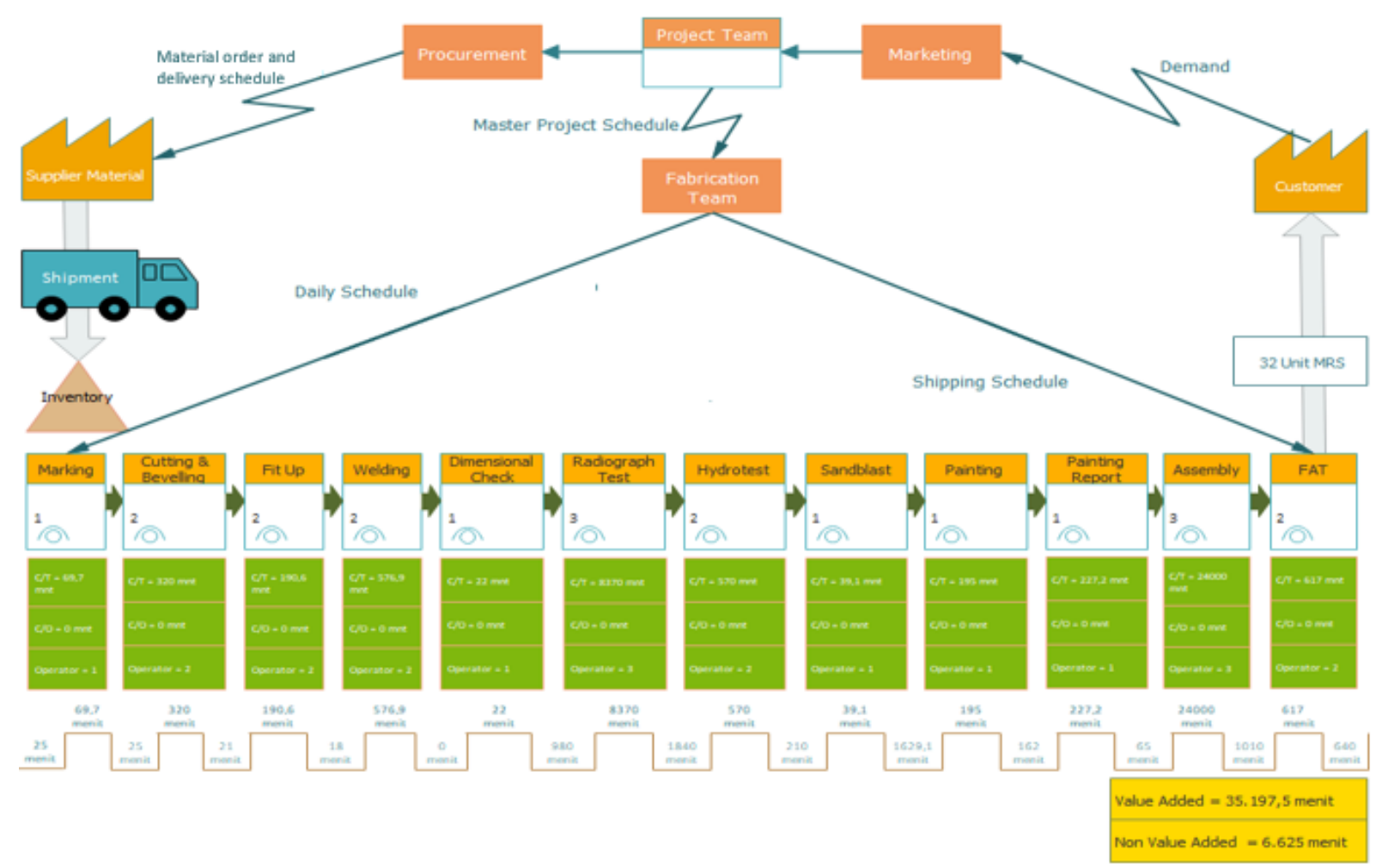

Figure 2. Current State Value Stream Mapping MRS Fabrication Process

\subsection{Identification and Measurement of Waste}

a. Seven Waste Relationship

The calculation of the relationship between wastes is carried out in discussion with related parties who are experts in their fields using the weighting criteria developed [29]. For each relationship, six scoring questions were asked which can be seen in Table 3.

Table 3. List of Questions for WRM Analysis

\begin{tabular}{|c|c|}
\hline Question & Answer Options \& Score \\
\hline Does $i$ produce $j ?$ & $\begin{array}{l}\text { a. Always }=4 \\
\text { b. Sometimes = } 2 \\
\text { c. Rarely }=0\end{array}$ \\
\hline $\begin{array}{l}\text { What is the type of relationship } \\
\text { between } i \text { and } j \text { ? }\end{array}$ & $\begin{array}{l}\text { a. If } i \text { increases, then } j \text { increases }=2 \\
\text { b. If } i \text { increases then } j j \text { is constant }=1 \mathrm{c} \text {. It does } \\
\text { not depend on the condition }=0\end{array}$ \\
\hline Impact on $i$ due to $j$ ? & $\begin{array}{l}\text { a. Direct and clear }=4 \\
\text { b. Takes time to appear }=2 \\
\text { c. } \text { Does not often appear }=0\end{array}$ \\
\hline $\begin{array}{l}\text { Eliminating the impact } \mathrm{i} \text { on } \mathrm{j} \text { can be } \\
\text { achieved by? }\end{array}$ & $\begin{array}{l}\text { a. Engineering method }=2 \\
\text { b. Simple \& direct }=1 \\
\text { c. Instructional solution }=0\end{array}$ \\
\hline The impact of i on j mainly affects? & $\begin{array}{l}\text { a. Product quality }=1 \\
\text { b. Productivity of resources }=1 \\
\text { c. Lead Time = } 1 \\
\text { d. Quality and productivity }=2 \\
\text { e. Quality and lead time = } 2 \\
\text { f. Productivity and lead time }=2 \\
\text { g. Quality, productivity, and lead time }=4\end{array}$ \\
\hline $\begin{array}{l}\text { How much impact will } i \text { on } j \\
\text { increase Lead Time? }\end{array}$ & $\begin{array}{l}\text { a. Very high }=4 \\
\text { b. Medium }=2 \\
\text { c. Low }=0\end{array}$ \\
\hline
\end{tabular}


Collecting questionnaire data on the relationship between seven types of waste was carried out by conducting discussions with the MRS specialist Supervisor who directly handles the MRS fabrication process. The reason is that only one person was chosen because in this questionnaire objectivity was needed so that it was necessary for respondents who already knew correctly about the manufacturing of MRS products as a whole. Discussions are conducted so that the understanding of the questions in the questionnaire is understood correctly and there are no different perceptions. The questions contained in the questionnaire refer to the methodology developed by [29] as an approach to measuring the relationship between types of waste.

\section{b. Waste Relationship Matrix (WRM)}

WRM is a matrix that is commonly used to describe the relationship between waste that occurs in the production line system [30]. The steps taken in making WRM were weighting the Seven Waste Relationship and then making WRM. The results of the weighted conversion of Seven Waste.

Relationship is used again to calculate the level of influence of each type of waste to other types of waste with conversion values $\mathrm{A}=10, \mathrm{E}=8, \mathrm{I}=6, \mathrm{O}=4, \mathrm{U}=2$ and $\mathrm{X}=0$. Results This calculation will then be added up and the value of the effect level is known, which is written in percent (\%). Following are the results of the Waste Relationship Matrix (WRM).

Table 4. Waste Relationship Matrix

\begin{tabular}{clllllll}
\hline F/T & $\mathbf{0}$ & $\mathbf{I}$ & $\mathbf{D}$ & $\mathbf{M}$ & $\mathbf{T}$ & $\mathbf{P}$ & $\mathbf{W}$ \\
\hline $\mathbf{0}$ & $\mathrm{A}$ & $\mathrm{U}$ & $\mathrm{U}$ & $\mathrm{U}$ & $\mathrm{U}$ & $\mathrm{U}$ & $\mathrm{U}$ \\
$\mathbf{I}$ & $\mathrm{X}$ & $\mathrm{A}$ & $\mathrm{U}$ & $\mathrm{U}$ & $\mathrm{O}$ & $\mathrm{O}$ & $\mathrm{I}$ \\
$\mathbf{D}$ & $\mathrm{U}$ & $\mathrm{U}$ & $\mathrm{A}$ & $\mathrm{U}$ & $\mathrm{U}$ & $\mathrm{U}$ & $\mathrm{O}$ \\
$\mathbf{M}$ & $\mathrm{U}$ & $\mathrm{X}$ & $\mathrm{U}$ & $\mathrm{A}$ & 0 & $\mathrm{I}$ & $\mathrm{E}$ \\
$\mathbf{T}$ & $\mathrm{U}$ & $\mathrm{U}$ & $\mathrm{O}$ & $\mathrm{I}$ & $\mathrm{A}$ & $\mathrm{E}$ & $\mathrm{I}$ \\
$\mathbf{P}$ & $\mathrm{U}$ & $\mathrm{O}$ & $\mathrm{I}$ & $\mathrm{E}$ & $\mathrm{I}$ & $\mathrm{A}$ & $\mathrm{A}$ \\
$\mathbf{W}$ & $\mathrm{U}$ & $\mathrm{U}$ & $\mathrm{O}$ & $\mathrm{I}$ & $\mathrm{I}$ & $\mathrm{A}$ & $\mathrm{A}$ \\
\hline
\end{tabular}

From Table 4 the WRM letters are converted with their respective scores so that the matrix table can be obtained as follows:

Table 5. Score Waste Relationship Matrix

\begin{tabular}{cccccccccc}
\hline $\mathbf{F} / \mathbf{T}$ & $\mathbf{0}$ & $\mathbf{I}$ & $\mathbf{D}$ & $\mathbf{M}$ & $\mathbf{T}$ & $\mathbf{P}$ & $\mathbf{W}$ & Score & $\mathbf{\%}$ \\
\hline $\mathbf{0}$ & 10 & 2 & 2 & 2 & 2 & 2 & 6 & 26 & $11 \%$ \\
$\mathbf{I}$ & 0 & 10 & 2 & 2 & 4 & 4 & 6 & 28 & $12 \%$ \\
$\mathbf{D}$ & 2 & 2 & 10 & 2 & 2 & 2 & 4 & 24 & $10 \%$ \\
$\mathbf{M}$ & 2 & 0 & 2 & 10 & 4 & 6 & 8 & 32 & $14 \%$ \\
$\mathbf{T}$ & 2 & 2 & 4 & 6 & 10 & 8 & 6 & 38 & $16 \%$ \\
$\mathbf{P}$ & 2 & 4 & 6 & 8 & 6 & 10 & 10 & 46 & $20 \%$ \\
$\mathbf{W}$ & 2 & 2 & 4 & 6 & 6 & 10 & 10 & 40 & $17 \%$ \\
Score & 20 & 22 & 30 & 36 & 34 & 42 & 50 & 234 & \\
\% & $9 \%$ & $9 \%$ & $13 \%$ & $15 \%$ & $15 \%$ & $18 \%$ & $21 \%$ & & \\
\hline
\end{tabular}

In table 5, it can be seen that the value that affects other waste with a large enough effect is from process, namely $20 \%$. Besides this, it can also be seen that the waste caused by other waste is waiting, it can be seen from the highest score to waiting, which is $21 \%$.

\section{c. Waste Assessment Questionnaire}

The Waste Assessment Questionnaire is designed to identify and allocate waste that occurs on the production line. The assessment questionnaire consists of 68 questions. Each question from the questionnaire represents an activity, condition or behaviour in production that might cause waste. Some questions are grouped into the "From" type which means that the question refers to all kinds of waste that occur which can trigger or produce types of waste different. Meanwhile, the other question represents the type of "to" which means all kinds of waste generated by other wastes. Each question on the WAQ consists of 3 answers with their respective weights: $1,0.5$, and 0 . The questions are categorized into 4 groups, namely man, machine, material and method. The recapitulation results 
of the WAQ assessment can be seen in table 6 . In table 6 , it can be concluded that the waste that is ranked first and most influential is caused by waiting waste.

Table 6. WAQ Recapitulation MRS Fabrication Process

\begin{tabular}{lccccccc}
\hline & $\mathbf{0}$ & $\mathbf{I}$ & $\mathbf{D}$ & $\mathbf{M}$ & $\mathbf{T}$ & $\mathbf{P}$ & $\mathbf{W}$ \\
\hline Score (Sj) & 17,57 & 23,57 & 29,51 & 40,31 & 40,18 & 47,18 & 52,16 \\
Frequency (Fj) & 50 & 45 & 55 & 55 & 55 & 55 & 55 \\
Score (hj) & 32,00 & 36,00 & 48,00 & 60,00 & 60,00 & 72,00 & 76,61 \\
Frequency (fj) & 62 & 57 & 68 & 68 & 68 & 68 & 68 \\
Score Yj & 2,26 & 1,93 & 2,01 & 1,84 & 1,85 & 1,89 & 1,82 \\
Pj Factors & 99,00 & 108,00 & 120,00 & 224,00 & 240,00 & 342,00 & 374,00 \\
Yj Final & 224 & 209 & 241 & 412 & 443 & 645 & 679 \\
The final result & $7,84 \%$ & $7,32 \%$ & $8,46 \%$ & $14,45 \%$ & $15,53 \%$ & $22,61 \%$ & $23,80 \%$ \\
\hline \multicolumn{1}{c}{ Rank } & $\mathbf{6}$ & $\mathbf{7}$ & $\mathbf{5}$ & $\mathbf{4}$ & $\mathbf{3}$ & $\mathbf{2}$ & $\mathbf{1}$ \\
\hline
\end{tabular}

\subsection{Identification of the Causes of Waste}

a. Selection of VALSAT tools

After getting the waste weight values using WRM and WAQ and knowing the most influential waste and need to be further identified is waste waiting, the next step is to choose the most appropriate tools using the VALSAT table. To determine the VALSAT tools used, namely by multiplying the final result (\%) of each waste with each category score in the VALSAT tools assessment table as in the table below, where the values of $H=9, M=3$ and $L=1$. The VALSAT Tools Assessment Table table can be seen in table 7.

Table 7. VALSAT Tools Assessment Table

\begin{tabular}{|c|c|c|c|c|c|c|c|c|c|c|c|c|c|c|c|}
\hline $\begin{array}{c}\text { Waste/ } \\
\text { Structure }\end{array}$ & Weight & \multicolumn{2}{|c|}{ PAM } & \multicolumn{2}{|c|}{ SCRM } & \multicolumn{2}{|r|}{ PVF } & \multicolumn{2}{|c|}{ QFM } & \multicolumn{2}{|c|}{ DAM } & \multicolumn{2}{|c|}{ DPA } & \multicolumn{2}{|r|}{ PS } \\
\hline $\begin{array}{l}\text { Over } \\
\text { production }\end{array}$ & 5,51 & $\mathrm{~L}$ & 5,51 & M & 16,53 & & & $\mathrm{~L}$ & 5,51 & M & 16,53 & M & 16,53 & & \\
\hline Waiting & 24,70 & $\mathrm{H}$ & 222,3 & $\mathrm{H}$ & 222,3 & $\mathrm{~L}$ & 24,70 & & & M & 74,1 & M & 74,1 & & \\
\hline $\begin{array}{l}\text { Transport } \\
\text { ation }\end{array}$ & 16,33 & $\mathrm{H}$ & 147 & & & & & & & & & & & $\mathrm{~L}$ & 16,33 \\
\hline $\begin{array}{l}\text { Over } \\
\text { Processing }\end{array}$ & 23,98 & $\mathrm{H}$ & 215,8 & & & M & 71,94 & $\mathrm{~L}$ & 23,98 & & & $\mathrm{~L}$ & 23,98 & & \\
\hline Inventory & 7,01 & M & 21,03 & $\mathrm{H}$ & 63,09 & M & 21,03 & & & $\mathrm{H}$ & 63,09 & M & 21,03 & $\mathrm{~L}$ & 7,01 \\
\hline Motion & 14,34 & $\mathrm{H}$ & 129,1 & $\mathrm{~L}$ & 14,34 & & & & & & & & & & \\
\hline Defect & 8,12 & $\mathrm{~L}$ & 8,12 & & & & & $\mathrm{H}$ & 73,08 & & & & & & \\
\hline \multicolumn{2}{|l|}{ Total } & \multicolumn{2}{|c|}{748,81} & \multicolumn{2}{|c|}{316,26} & \multicolumn{2}{|c|}{117,67} & \multicolumn{2}{|c|}{102,57} & \multicolumn{2}{|c|}{153,72} & \multicolumn{2}{|c|}{135,64} & & 3,34 \\
\hline
\end{tabular}

Based on the VALSAT tool selection table above, it can be concluded that Process Activity Mapping (PAM) is the chosen VALSAT tool with a score of 748.81.

\section{b. $\quad$ Making Process Activity Mapping}

Process Activity Mapping (PAM) was made in order to determine the process flow in more detail, where in this study the MRS product process flow. The output of the process activity mapping that has been made is total value added time, necessary non value added time, not value added time and lead time. From the grouping of activities carried out in PAM, it can be seen what activities are most dominant in the production line. as for the percentage table is as follows:

Table 8. Results of PAM MRS

\begin{tabular}{lc}
\hline Lead time (minutes) & 41822,60 \\
Total Value Added Time (minutes) & 35197,5 \\
\% Value Added Time & $84,16 \%$ \\
Total Necessary Non Value Added Time (minutes) & 3010,1 \\
\% Necessary Non Value Added Time & $7,20 \%$ \\
Total Non Value Added Time (minutes) & 3615 \\
\% Non Value Added Time & $8,64 \%$ \\
\hline
\end{tabular}




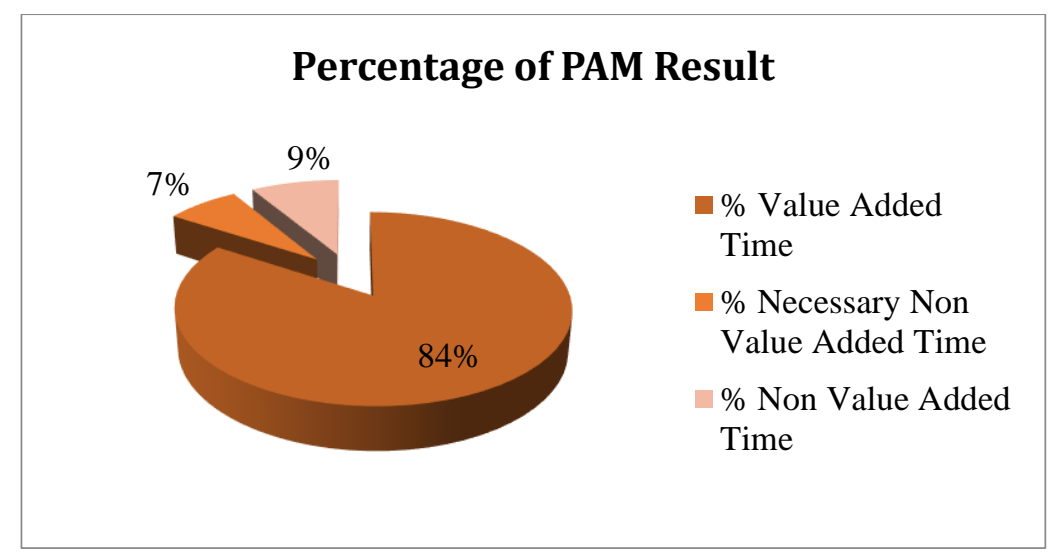

Figure 3. Results of the PAM MRS Presentation

From the identification of waste using the Process Activity Mapping (PAM) and Waste Assessment Model (WAM) that has been made, it can be concluded that in the MRS fabrication process at Company YS there is the most influential waste in the form of Waiting. Waiting activity is often the reason for production delays and other wastes, where the waiting process has a direct impact on lead time. The waiting that occurs based on the process activity mapping are:

1. Waiting for teams from other companies. This waiting occurs because a team from another company that functions as testing and inspector does not arrive on time, causing the other fabrication process to also delay from the scheduled time.

2. Waiting for the assembly process, which waits for all MRS units to be completed in assembly first, then the Factory Acceptance Test is carried out so that material build-up occurs in the area.

\subsection{Cause and Effect Analysis and Recommendations for Improvement}

To find out the root cause of the waste, it will be analysed using a fishbone diagram. Fishbone diagram is a diagram that describes the cause and effect of a problem. In this case, 4 parameters are used in assessing the existing problem, namely in terms of method, man, material, and machine (equipment). The following is a fishbone diagram of the type of waste in the form of the most influential waiting time with the highest level of urgency and the results can be seen in Figure 4. below.

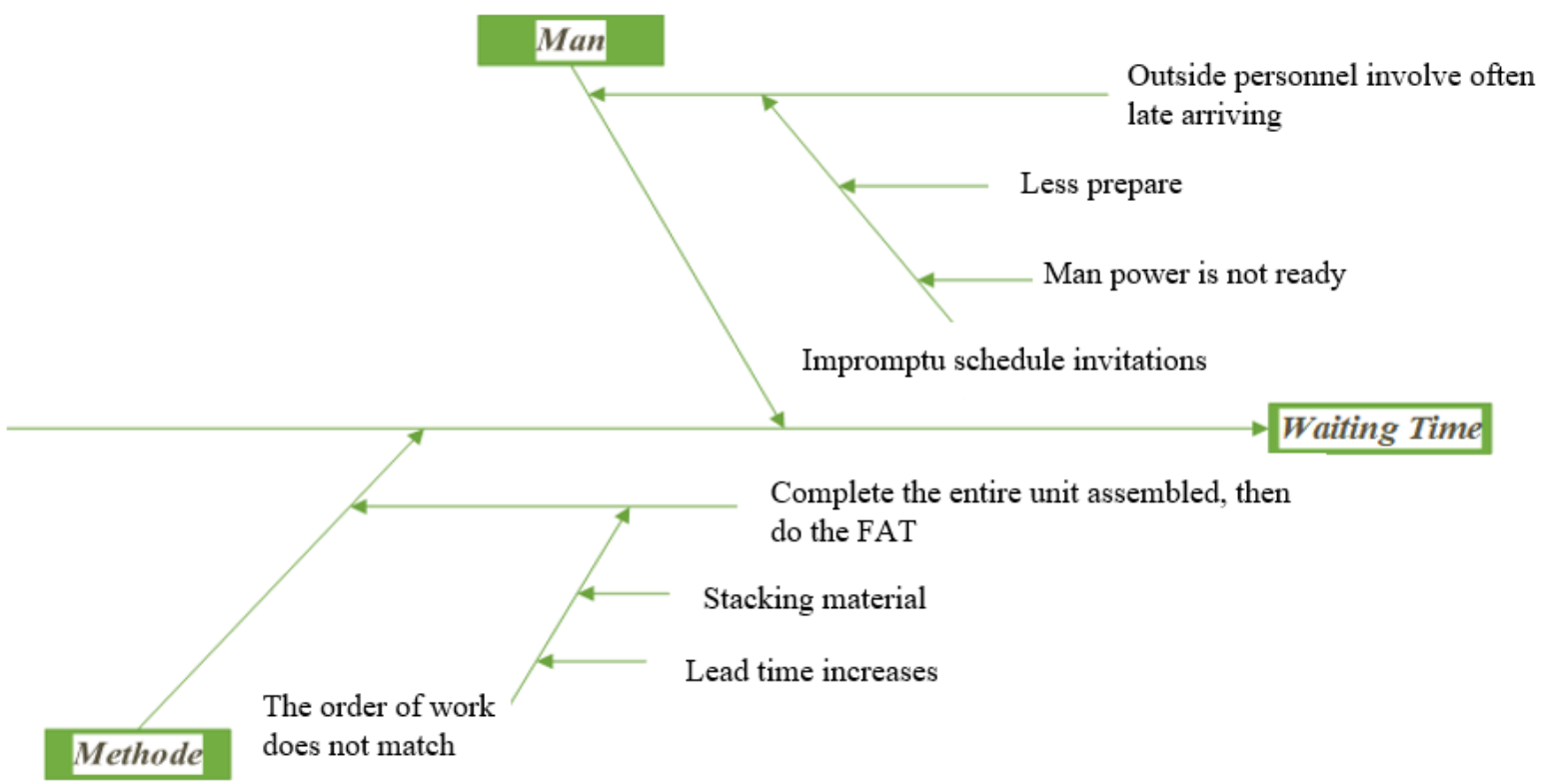

Figure 4. Fishbone Diagram

With the fishbone diagram, it is obtained the causes and effects why waste waiting time occurs. After knowing the root cause of waiting time that occurs in the production process, the next step is to make improvements. Following are the remedial measures given to reduce wasteful waiting time: 
Table 9. Waste waiting improvement recommendations

\begin{tabular}{|c|c|c|c|}
\hline Factor & Cause & Effect & Recommendation Improvement \\
\hline Man & $\begin{array}{l}\text { Teams from other } \\
\text { companies that } \\
\text { functioned as testers } \\
\text { and inspectors did not } \\
\text { arrive on time }\end{array}$ & $\begin{array}{l}\text { The rest of the } \\
\text { fabrication } \\
\text { process was } \\
\text { delayed from the } \\
\text { scheduled time. }\end{array}$ & $\begin{array}{l}\text { 1. Make an invitation for the implementation } \\
\text { activity not suddenly, or a maximum of D-5 } \\
\text { before the implementation time. } \\
\text { 2. The implementation time stated in the } \\
\text { invitation, is advanced approximately } 30 \\
\text { minutes before the implementation time. }\end{array}$ \\
\hline Method & $\begin{array}{l}\text { Waiting for all MRS units } \\
\text { to finish in assembly } \\
\text { first, then do the Factory } \\
\text { Acceptance Test }\end{array}$ & $\begin{array}{l}\text { Stacking of } \\
\text { materials \& } \\
\text { increased lead } \\
\text { time }\end{array}$ & $\begin{array}{l}\text { Assembly and FAT activities are carried out in } \\
\text { parallel. Each MRS unit that is finished } \\
\text { assembling goes directly to the FAT process. }\end{array}$ \\
\hline
\end{tabular}

After knowing the recommendations for improvements in order to minimize wasteful waiting, a Process Activity Mapping will then be made after the repair. This aims to ensure that the recommendations for improvement given are correct and can be implemented by the company. From the PAM table after improvement, the percentage table results are as follows:

Table 10. Results of PAM MRS after improvement

\begin{tabular}{lc}
\hline Lead time (menit) & 35055,60 \\
Total Value Added Time (menit) & 30530,5 \\
$\%$ Value Added Time & $87,09 \%$ \\
Total Necessary Non Value Added Time (menit) & 3010,1 \\
$\%$ Necessary Non Value Added Time & $8,59 \%$ \\
Total Non Value Added Time (menit) & 1515 \\
$\%$ Non Value Added Time & $4,32 \%$ \\
\hline
\end{tabular}

\section{Percentage of PAM Result after improvement}

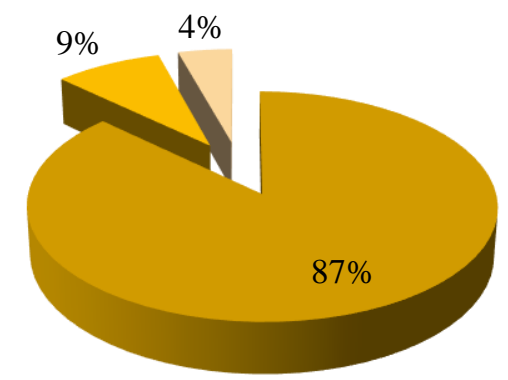

\% Value Added Time

$\%$ Necessary Non Value Added Time

$\%$ Non Value Added

Time

Figure 5. Results of PAM MRS presentation after improvement

\subsection{Making a Future Value Stream Mapping}

After providing recommendations for improvements, the next step is to describe the Future Value Stream Mapping. Future Value Stream Mapping in the MRS fabrication process can be seen in Figure 6. 


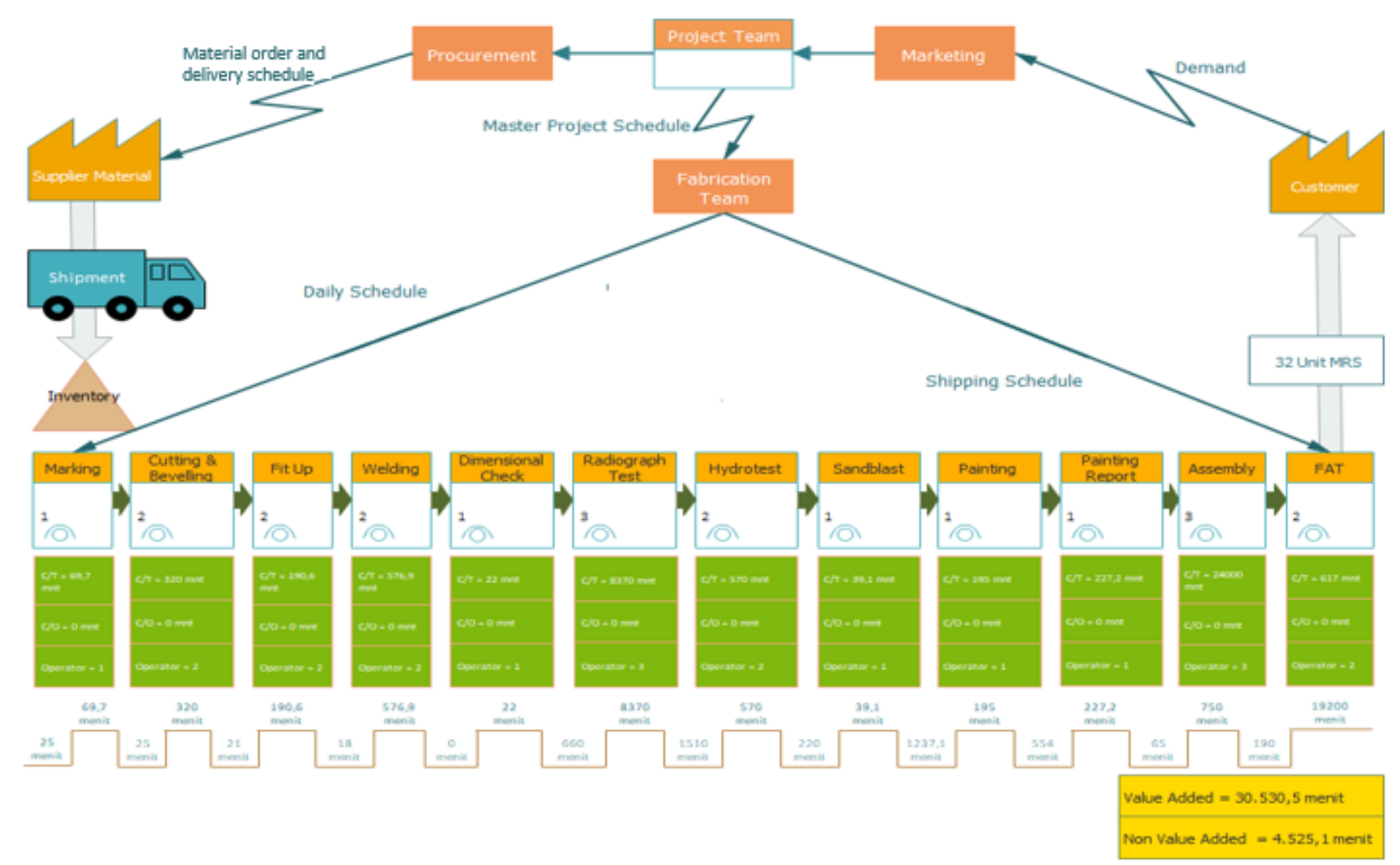

Figure 6. Future State Value Stream Mapping MRS Fabrication Process

\section{Results and Discussions}

From the calculations that have been done, the following comparisons are obtained:

Table 11. Comparison of the duration before and after improvement

\begin{tabular}{lcc}
\hline & Before & After \\
Lead time (menit) & $41.822,60$ & $35.055,60$ \\
Total Value Added Time (menit) & $35.197,5$ & $30.530,5$ \\
\% Value Added Time & $84,16 \%$ & $87,09 \%$ \\
Total Necessary Non Value Added Time (menit) & $3.010,1$ & $3.010,1$ \\
\% Necessary Non Value Added Time & $7,20 \%$ & $8,59 \%$ \\
Total Non Value Added Time (menit) & 3.615 & 1.515 \\
\% Non Value Added Time & $8,64 \%$ & $4,32 \%$ \\
\hline
\end{tabular}

In the initial conditions, the lead time is $41,822.60$ minutes or 99 working days with the percentage of work done is $84 \%$ VA, $7 \%$ NNVA and $9 \%$ NVA. So that the fabrication process of 32 MRS units experienced a delay of 13 days from the predetermined schedule. However, after making improvements according to the recommendations, the lead time was 35,055.60 minutes or 83 working days with the percentage of work done was $87 \%$ VA, 9\% NNVA and 4\% NVA. So that the fabrication process of 32 MRS units was 3 days earlier than scheduled (the schedule was given 86 working days).

\section{Conclusion}

The cause of delays in the Metering Regulating System (MRS) procurement project, especially in the fabrication process, is the waiting process. Several activities on wasted Waiting that do not add value when the MRS fabrication process needs to be eliminated, namely the waiting process from the testing team and the inspectors because they do not arrive on time and there are still errors in the order of work which need to wait for all MRS units to be completed at the assembly first, then the Factory Acceptance Test (FAT) is carried out. There are some recommendations for improvement such as making an invitation for the implementation activity not suddenly, a maximum of D-5 before 
the implementation time and the implementation time stated in the invitation is advanced approximately 30 minutes before the implementation time. Assembly and FAT activities are carried out in parallel. Each MRS unit that is finished assembling goes directly to the FAT process.

By implementing these improvement recommendations, the lead time for the fabrication process was obtained from 41,822.60 minutes or 99 working days to $35,055.60$ minutes or 83 working days so that the fabrication process could be completed 3 days earlier than scheduled. Thus the proposed improvements in this study can be applied to minimize delays in the MRS fabrication process in the following years.

\section{References}

[1] R. Muri, G. S. Gandara, A. P. Wirani, and S. Hasibuan, "Analysis of Production Process to Improve Lead Time and Productivity in Fabrication by using Lean Methodology. Case Study in Turbine Component ...," Ijresm.Com, no. 7, 2019.

[2] M. Kholil, Hendri, B. Hanum, and R. Setiawan, "Using 7 waste approach and VSM method to improve the efficiency of mackerel fish crackers production time at small medium enterprise (SME)," Proc. Int. Conf. Ind. Eng. Oper. Manag., vol. 2018-March, pp. 2819-2826, 2018.

[3] M. Kholil, A. Chandra, and B. Hanum, Perencanaan Pengendalian Produksi \& Logistik. Jakarta: Mitra Wacana Media, 2019.

[4] B. Carreira, Lean Manufacturing That Works_ Powerful Tools for Dramatically Reducing Waste and Maximizing Profits. New York: AMACOM, 2005.

[5] A. Hipni, "Penerapan Lean Manufacturing Pada Perancangan Painting Plant Untuk Mengatasi Keterlambatan (Studi Kasus PT . Koba Multi Indonesia)," S2 thesis, Univ. Mercu Buana Jakarta, 2019.

[6] S. Thamizhmanii and S. Hasan, "A review on an employee empowerment in TQM practice," vol. 39, no. 2, pp. 204-210, 2010.

[7] U. K.W.D., "Lean Manufacturing Application in Identifying and Minimizing Waste Granite Products in the Production Division of PT XYZ," 2013.

[8] N. West and S. Africa, "LEAN IMPLEMENTATION STRATEGIES: HOW ARE THE TOYOTA WAY PRINCIPLES ADDRESSED? R. Coetzee 1\#* , K. van der Merwe 2 \& L. van Dyk 1 ARTICLE INFO," vol. 27, no. November, pp. 79-91, 2016.

[9] S.-G. Toma and S. Naruo, "Total Quality Management and Business Excellence: The Best Practices at Toyota Motor Corporation," Amfiteatru Econ., vol. 19, no. 45, pp. 566-580, 2017.

[10] T. Wahyudi and E. All, Buku Pedoman Astra Total Quality Control. Jakarta: PT. Astra International, 1990.

[11] A. Hirzel, M. Leyer, and J. Moormaan, "The role of employee empowerment in the implementation of continuous improvement: Evidence from a case study of a financial services provider," Int. J. Oper. Prod. Manag., vol. 37, no. 10, pp. 1563-1579, 2017.

[12] R. S. Mclean, J. Antony, J. J. Dahlgaard, R. S. Mclean, J. Antony, and J. J. D. Failure, "Total Quality Management \& Business Excellence Failure of Continuous Improvement initiatives in manufacturing environments : a systematic review of the evidence," vol. 3363, no. January, 2016, doi: 10.1080/14783363.2015.1063414.

[13] D. Shah and P. Patel, "Productivity Improvement by Implementing Lean Manufacturing Tools In Manufacturing Industry," Int. Res. J. Eng. Technol., vol. 5, no. 3, pp. 3794-3798, 2018.

[14] H. Purba, D. Santoso, and J. Haekal, "5S APPLICATION TRAINING ( SEIRI , SEITON, SEIS Ō, SEIKETSU , AND SHITSUKE ) TO IMPROVE THE QUALITY OF WORK ENVIRONMENT IN THE SERVICE INDUSTRY," no. 2014, pp. 2014-2016, 2016.

[15] V. Gaspersz, Total Quality Management. Jakarta: PT. Gramedia Pustaka Utama, 2005.

[16] D. Samuel, "How did the publication of the book The Machine That Changed The World change management thinking ? Exploring 25 years of lean literature," Int. J. Oper. Prod. Manag., vol. 35, no. 10, pp. 1-29, 2015.

[17] A. Naro and N. Halimah, "PERANCANGAN LEAN PRODUCTION SYSTEM PADA LINI PRODUKSI PANEL LISTRIK TIPE WALL MOUNTING DENGAN,” vol. XIII, no. 1, pp. 61-71, 2019.

[18] M. Braglia, G. Carmignani, F. Aldo, Z. Icpr, and A. New, "18th ICPR paper : A NEW VALUE STREAM MAPPING APPROACH FOR COMPLEX PRODUCTION SYSTEMS Marcello Braglia, Gionata Carmignani , Francesco Aldo Zammori To cite this version :," 2010.

[19] R. K. Mahendra and A. Susanty, "Analisis Efisiensi Kinerja Proses Produksi Briket Dengan Metode Value Stream Analysis Tools ( VALSAT ) di CV Mega Briquette Semarang." 
[20] I. S. A, R. N. R, and F. Rachman, "Analisis Waste dengan Menggunakan Value Stream Analysis Tools ( Valsat ) pada Proses Produksi Klip ( Studi Kasus di PT . Indoprima Gemilang Engineering)," pp. 400-406.

[21] M. Kholil and R. Mulya, "Minimasi Waste Dan Usulan Peningkatan Efisiensi Proses Produksi Mcb (Mini Circuit Breaker) Dengan Pendekatan Sistem Lean Manufacturing (Di PT Schneider Electric Indonesia)," vol. VIII, no. 1, pp. 44-70.

[22] E. Supriyanto, K. Program, S. Teknik, I. Fakultas, and U. N. Bandung, “"manufaktur" dalam dunia teknik industri," vol. 3, no. 3, pp. 3-6, 2013.

[23] J. Heizer and B. Render, "Operations Management -10th Edition 2011 - JayHeizer \& Barry Render.pdf." Pearson Education Inc., New Jersey, p. 890, 2011.

[24] S. Wenchi, J. Wang, X. Wang, and H. Chong, "AN APPLICATION OF VALUE STREAM MAPPING FOR TURNAROUND MAINTENANCE IN OIL AND GAS INDUSTRY: CASE STUDY AND LESSIONS LEARNED," no. September, pp. 813-822, 2015.

[25] D. Luiz et al., "A lean six sigma framework for continuous and incremental improvement in the oil and gas sector," vol. 11, no. 3, pp. 577-595, 2019, doi: 10.1108/IJLSS-02-2019-0011.

[26] E. Amrina, N. T. Putri, and D. M. Anjani, "Waste assessment using lean manufacturing in rubber production Waste assessment using lean manufacturing in rubber production," 2019, doi: 10.1088/1757-899X/528/1/012051.

[27] M. F. Septiani and et al, "The reduction of waste on pile production process using value stream analysis tool ( VALSAT ) method The reduction of waste on pile production process using value stream analysis tool (VALSAT ) method," IOP Conf. Ser. Mater. Sci. Eng., vol. 697, no. 012006, 2019, doi: 10.1088/1757-899X/697/1/012006.

[28] Adriansyah;, A. Sutanto, and B. Yuliandra, "Aplikasi Konsep Produksi Ramping untuk Memperbaiki Efisiensi Pengolahan Minyak Kelapa Sawit," J. Energi dan Manufaktur, vol. 11, no. 2, pp. 36-41, 2018, doi: 10.24843/JEM.2018.v11.i02.p01.

[29] I. A. Rawabdeh, "A model for the assessment of waste in job shop environments," 2004, doi: 10.1108/01443570510608619.

[30] A. Mughni, "Penaksiran waste pada proses produksi sepatu dengan waste relationship," 2005. 